\title{
SYRIAN CIVIL WAR: A HUMANITARIAN CRISIS
}

\author{
DR. RANI ERUM \\ Department of Political Science \\ Federal Urdu University of Arts, \\ Science and Technology, Karachi, Pakistan \\ http://www.rani.irum@fuuast.edu.pk \\ https://orcid.org/0000-0002-3845-8899
}

\begin{abstract}
The Syrian crisis is one of the most extensive issue of Middle East. The enduring fight among Baathist regime and factions of rebellion groups created a humanitarian dilemma in the country. Since 2011 the people of Syria are in complete despair, every dawn increases the intensity of their misery. The high amount of civilian deaths and destruction of infrastructure turned the country in to complete turmoil. Every day thousands of Syrian entre in Greece and Turkey for refuge and security, many among them died during this process which regularly shows on television screens but regional and internal actors are looking completely disable to do any significant effort to settle the conflicts among opponents of crisis. Therefore, the peace prospects are not very hopeful because the ongoing clashes frequently sabotage every effort between the combatants. This study design to discuss the reasons, consequences and effects of civil war on Syrians and enlightened the direct and indirect role of regional and Western powers in the past seven years.
\end{abstract}

\section{KEYWORDS}

Arab Spring, Rebellions, Civil War, Humanitarian Crisis, Sectarianism, Authoritarianism

\section{INTRODUCTION}


The clash between the minority of Shiite's and majority of the Syrian Sunnis was not the only reason of Syrian civil war but it is also a scuffle between 13 modest groups and Syrian regime. The Syrian population comprise with $75 \%$ Sunni's and only $11.5 \%$ Shia Alawites but the government belongs to the Alawites (Bashar-al- Assad regime). It was the major reason of conflict in the country. The animosity of factions, bias support and absence of coordination created turmoil and increases the conflict's intensity. More over the multiethnic dispersion generated mutual distrust and sectarian bigotry within the terrain as a result of this millions of people lost their lives and war has forced half of the population to flee into neighboring countries which causes the socio-economic and political destabilization effect on these countries. The Syrian refugee outflow has now directed towards West, transforming the greatest refugee crisis ever since World War II which also testifying the solidarity of European and international organizations. The world still not identify the solution of such a massive humanitarian crisis and working on its multiple resolutions.

\section{HISTORICAL BACKGROUND OF SYRIA}

Syria is the historical land situated in Middle East, bordering with Turkey, Lebanon, Jordon, Iraq and Israel. It came into being in 1916 under the Sykes-Picot agreement (Taki, 2012). The agreement also called "Asia Minor Agreement" (Encyclopedia Britannica, 2020). It was a secret convention between British and French governments during the World War I for deciding the future of the territories of Ottoman Empire, after forthcoming defeat of Turkey against Great powers. Formerly, it was one of the provinces of Ottoman Empire but much larger than today and consisting territories of Lebanon, Syria, and Jordan Palestinian and also included some parts of Turkey and Iraq and called 'Greater Syria'. After the formation of League of Nations in 1920, the entire Middle East was specified to its mandatory council who given it to France in 1921 for the purpose of assistance in administration because at that time it was not ready to hold sovereign state status. Therefore, it declared its official independence in 1946. 


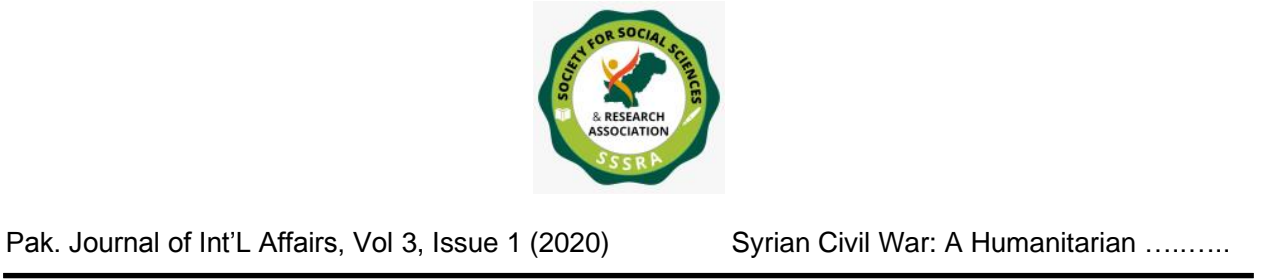

Syria never gets stabilized Government till 1970 when General Hafez alAssad the minister of defense came into power and announced himself Prime Minister and later President in 1971. Before Hafiz al-Assad, the newly born state was sprung between one regime to another and the average tenure of every government was less than one year until 1964 when Ba'ath party coup and made effort to establish strong Syrian regime but failed. Hafiz al-Assad not only divided Ba'ath party and communities of the state for the sake of strong control over the administration but also tried to consolidate the power of government more and more in his family. $\mathrm{He}$ himself belonged from Alawite community therefore specifically preferred them and primarily giving them control over the all state security organs and gradually promoting them on high administrative places. Alawite are Shia Muslims who were minor in number ruled on majority of Sunni Muslims in Syria. Despite of this ethnic disparity Hafiz al-Assad managed to control the dictatorial government for next 30 years without any major conflict. He also formed close ties with Soviet Union and Iran. He adopted pro-Palestinian policy according to the sentiments of Syrians who reviled Western policies for Israel, and wanted back their fertile land of Golan Heights which was occupied by Israel in 1967. Thus, people were not against their regime.

\section{ETHNIC DIVISION OF SYRIA}

Modern Syria is manifest by its mixed ethnic and religious groups. It consists of $75 \%$ Sunni Muslims, $11.5 \%$ Alawis, 3.0\% Druzes, $1.5 \%$ Isma'ilis, and $4.7 \%$ the Greek Orthodox Christians (Baltes, 2016, p.8). Whereas on the other side minorities also divided into multiple ethnic branches. They have $8.5 \%$ Kurds, 4\% Armenians, 3\% Turcomans and Circassians (Baltes, 2016, p.8).

\section{ORIGIN OF THE SYRIAN CRISIS}

During the 1980s, the Muslim Brotherhood, who belonged to Sunni Muslims took advantage of ethnic resentment and gradually increase their influence and eventually posed a major threat to the Baathists regime. But those threats were not immediately effect to Hafez al-Assad because people respected him because of fear as he was not seen often in public and did not 


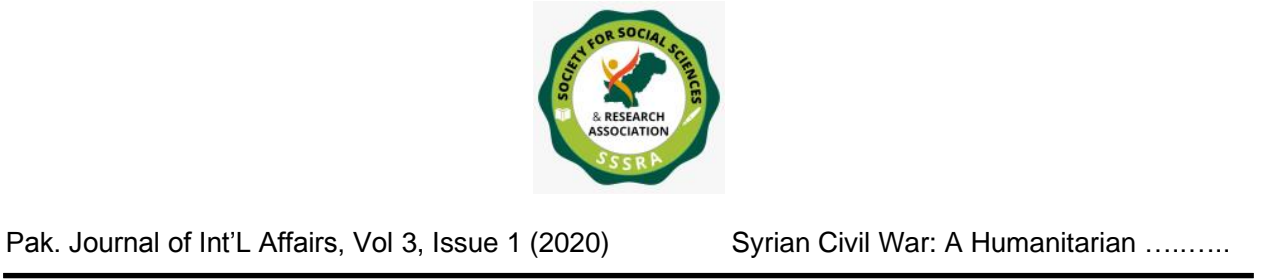

communicate much with the people (Haran, 2016). He groomed his son Bashar, for succession of his place in the government from several years, but still his death in June 2000 was seemed early due to some technical complications of constitution of Syria. The Syrian Constitution specified minimum 40 years age limit for president whereas, Bashar was only thirtyfive years old. It would take a constitutional amendment for him to become president. Parliament convened and immediately amended the constitution to lower the qualifying age to thirty-four. Bashar al- Assad became president and later ran unopposed in a contrived election, receiving 97.29 percent of the vote (Erlich, 2014, p.40). People of Syria expected young Assad to reform the system because he was educated from West and his lifestyle depicted modernization but all his approach profited his own wealth and Syrian People attained very less benefits of Junior Assad's policies. Apart from less economic benefits his relations with West also create hostility among the people. Baath Party is the only legal political party according to Syrian Constitution. Junior Assad promised to amend the constitution and allow multi-party system which he did. He also did some major social and economic reforms for the country therefore he believed that he was the face of modern Syria and most popular leader of people.

\section{BEGINNING OF SYRIAN CIVIL WAR}

After getting complete control on Syria, Bashar-al Assad believed that his government achieved enough stability that nothing would be affecting it. In a last week of January 2011, he publicized his views in his interview with The Wall Street Journal, in which he expounded that Syria was not only attained stability but he, himself had developed close relations with all ethnies of his country. He also warned Arab leaders of neighboring countries about the lack of reforms, he said,

"If you didn't see the need of reform before what happened in Egypt and Tunisia, it's too late to do any reform" (Solomon and Spindle, 2011). 


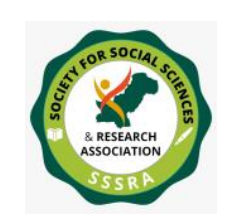

This interview was given by Assad almost one month before the Arab spring knocked Syria, which showed that how much he was associated with his people and how much he was aware the ground realties of his own country. This confidence of Bashar was based on some of his actions in terms of improving economic conditions of his nation since 2005 with collaboration of IMF (International Monetary Fund). His first aim was socio-economic transformation of Syria and then democratization. He wanted to impose his own kind of reforms to the country without understanding the factual disparities of his nation. That over confidence led him to react brutally against Arab spring in Syria.

The uprising of Tunisia was a democratic wave which blowout in Middle East as Arab Spring. It was an outcome of frustration of people and failure of autocratic regimes in all over the Middle East. The Arab uprising was born out of a "broad set of ideas and grievances that are motivating" change (Jones, 2012). Whereas, in Syria it was initially a minor protest which was against regime's educational policies and open corruption like local issues. It was began in Dar'a (a southwestern city of Syria) where 20 children tinted the walls with 'we want freedom' on a street, police officers caught protesters and sent them directly to jail where they received immoral conduct (Lefèvre, 2013, p.183). After the cruel response of the governmental officials, the peaceful rallies in Dar'a turned from the domestic clash into a widespread revolt. By June 2011 over 500 people had been killed and brutal authority actions forced thousands of Syrian residents to flee into Turkey, marking the beginning of large- scale refugee movements (Ferris \& Kirişci, 2016, p.14). The opposition forces utilized the situation and raised their socio-political and economic demands for the country such as elating the emergency law, guaranteeing political participation and independent media. The efforts of people of Syria were more related with their own ideological and political modernization rather than self-indulgence or identity politics. The sectarian and extreme violent protests were started later as 'New Wars'. The Free Syrian Army was officially organized by major Syrian opposition movement under the leadership of Riad Al-Assad, in July 2011. He was a former Syrian army colonel. On the other hand government increased deadly military assaults including dropping barrel bombs on cities such as Aleppo, laying siege to 
rebel-held areas, and using of chemical weapons (Ferris \& Kirişci, 2016, p.15). International actors support every new alliance of opposition forces since then. The aim of every group is to get rid the Assad regime transformed the country in a democratic state. The most inclusive organizations are the National Coalition for Syrian Revolutionary and Opposition Forces, supported by the Syrian National Council, the Local Coordination Committees and the Free Syrian Army (Baltes, 2016, p.50). Apart of aggressive action some parties still believed in peaceful negotiations with government like National Co-ordination Committee. The goal of National Coalition is to build a stable democratic state with safeguarding the integration of the Syrian people. Some Islamist militant groups also reject violence and want to negotiate with the government. Arab league and United Nations made effort to provide communication channel between Syrian regime and opposition groups by organizing the negotiation meetings to work towards the peace in the country but yet no positive result has been achieved. United Nations Security Council passed resolution 2254 in December 2015 for supporting efforts to pursue a political solution to the conflict in Syria, but no positive change had been occurred in the country. Instead situation has getting worse by every passing day. Today a wide range of dissident groups are fighting with the regime and each other, stretching from the Western-backed Free Syrian Army to Islamist groups such as the al-Nusra Front and ISIS (Ferris \& Kirişci, p.15)

The Syrian civil war was not remained a domestic issue but gradually gathered international attention and support. The Sunni opposition obtains support of Sunni Gulf states and Turkey as well as radical militant groups whereas; Assad regime supported by Iran, Lebanon, Hezbollah, Iraq and Iraqi Shiite militants and Russia. The support was not just political or humanitarian but it was rather a complete military assistance. Since 2015 Russia, Iran and Hezbollah deployed military force for the help of Syrian government and opposition groups acquiring lethal and non-lethal support from different countries of the world. The circumstances bring the ethnic divide of Syria and huge humanitarian crisis which led the country towards calamity. 
Second region is in control of Militant Islamic organization of IS (Islamic State) which rule over the eastern region of country including Deir-ez-Zor and Raqqa's oil fields and Arab tribal areas near the borders of Iraq and has declared a "caliphate," which also takes in a large part of Iraq. Third region controlled by Kurd influenced Parties in northeast region and a bit of west Kurd population region of Syria.

\section{ACTORS OF SYRIAN CIVIL WAR}

The civil war divided Syria in to four regions which controlled by multiple groups. These groups become major players of the war from last eight years. They are not only governing the land but also imposed their so called dogmas as law in their respective region. This diverse controlling turned one country in to different indigenous edifices.

\section{THE REGIME}

The first region controlled by Bashar -al- Assad regime which includes capital city of Damascus and rich coastal areas along with some rural areas. The Assad regime's forces holds probably 100.000 and 200.000 armed forces. They possessed heavy military weapons, armoured personnel carriers and artillery. Proficient armed technology gave Assad regime an edge to other groups. The regime forces getting lead in the direct military clashes with the protestors. Regime holding the support and loyalty of vast majority of the Alawite community for several reasons such as a large number of them are employed in the regime's security forces. Secondly, Alawites holds most of the high military posts, thirdly Assad himself belongs to the same sect thus they are the strong supporters of Regime. Instead of sectarian connection they also afraid of retaliation by the Sunni majority in a case of Assad's culmination. The regime retreat divisions are also cautious to not hurt any Alawite areas.

\section{THE OPPOSITION}

The opposition of Assad regime is divided in to three major groups. The division of opposition confuses the international community. Currently, 
dominant resisting coalitions are; Syrian National Council, National Coordination Body for Democratic Change, Free Syrian Army.

\section{- THE SYRIAN NATIONAL COUNCIL (SNC)}

The Syrian National Council (SNC) was formally formed in Turkey by exile Syrian Sunni activists in October 2011. Most fellows of SNC related with the Ikhwan-ul-Muslimu. It serves as a connection with international community, but it is not very united internally and it also lack in efficiency. They are in favor of international military intervention, therefore many Syrians in the country considered them as an instrument of the external and regional authorities.

\section{- NATIONAL COORDINATION BODY FOR DEMOCRATIC CHANGE (NCB)}

The NCB is also known as The National Coordination Committee for Democratic Change (NCC). It belongs to the anti-regime bloc of Syria which includes many enduring revolutionists, who are anxious of Islamists within the SNC. Unlike other opposition groups the NCB is willing to negotiate with Assad's regime, a part of opposing military involvement and interference of Moscow.

\section{- FREE SYRIAN ARMY (FSA)}

The Free Syrian Army was created by Sunni soldiers in March 2012 by thousands of Syrian soldiers who were against the regimes actions against civilians and lower positions in military because Assad regime trusted on Alawite religious group for high military ranks and officials. Mostly soldiers of this group are rudimentary trained who can use only light-arms. His leader is Riyad al-Asaad who commanded around 40.000 men according to his own claim.

- OTHER ETHNIC MINORITY GROUPS 


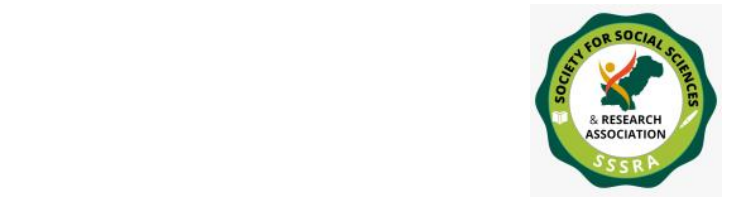

Syrian Civil War: A Humanitarian

Syrian Kurds and Christens are not involved in this uprising because generally they are neutral but inside they are in support of Assad regime and have fear of deceptive sectarian character of the current hostilities. Particularly Christens are believed that the sectarianism may end in suppressions against the minorities.

\section{POLITICAL CRISIS TURNED INTO HUMANITARIAN CRISIS}

The political conflict soon turned into humanitarian crisis because of inhuman violent actions of Assad regime and cruel retaliating attacks of opposition groups. The regime used most fatal weapons against its own population without any pre-announcement for civilian population. They are bombing on the cities for hours without taking care of schools, hospitals or religious places. These attacks turned many cities into ruins. According to the Syrian Center for Policy Research (SCPR), the fatalities because of the conflict till February 2016 was 470,000 (Human Rights Watch, 2017). Billions of people are displaced; suffering from starvation and unsheltered life but no group has mercy on them.

Regime forces used 13 types of different globally prohibited cluster weapons in over 400 attacks on opposition controlled areas resulted killing and injuring civilians, including children during July 2012 to August 2016 (Human Rights Watch, 2017). Initially global leaders presumed Syrian issue as a domestic problem but after using of WMDs by Syrian regime they were also apprehends the seriousness of crisis. A chemical weapons attack occurred by Bashar administration on outside of Damascus on Aug. 21, 2013 and killed up to 1,400 civilians, this attack almost fetched the U.S. on the edge of a armed intrusion in Syria, but Barack Obama dragged back at the last moment after Putin's offer of a negotiator in forthcoming deal under which Syria would hand over its chemical weapons (Manfreda, 2018).

In the meanwhile, an ISIL or the Islamic State of Iraq and the Levant, had arrived east Syria and taken control on large territory and made the city of Raqqa as ISIL's temporary capital. The use of brutal tactics and so called Islamic laws imposed effective control over the region along with empowering their allies and crushing their enemies (Weiss \& Hassan, 2016, 


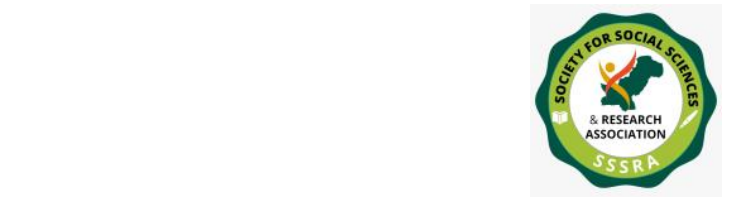

p.135). Washington launched airstrikes in Raqqa and Kobani in 2014 against ISIS but it did not made any effect on militant organization.

In 2017 the Joint Investigative Mechanism between the Organization for the Prohibition of Chemical Weapons (OPCW) and the UN determined that regime forces once again used prohibited weapons in March 2015 in an attack in Idlib. The investigation also discovered that ISIS had used sulfur mustard gas in August 2015 against armed opposition groups. The joint investigation also articulates that government helicopters dropped barrel bombs with toxic chemicals on opposition-controlled parts of Aleppo city on August 10 and September 6 (World Report of Human Rights Watch, 2017). The UN conducted inquiry also reported two more chemical attacks by Syrian regime and one attack by IS in early 2016. Despite of use of incendiary weapons, regime led forces bombing residential areas of different urban and rural parts of the country which made civilian life more miserable.

\section{CIVILIAN OPPRESSIONS BY ASSAD REGIME}

The Human Rights Watch report of 2016 articulates that the systemized civilian persecution by governmental officials in different parts of regime controlled places is increased. According to the testimony random imprisonment, maltreatment, torment, and forced desertions by regime forces are become the routine. Deaths during custody, extensive torture, abuse, poundings, famine and ailment resulting at least 12,679 persons dying in custody between March 2011 and June 2016, conferring by native observers (World Report of Human Rights Watch, 2017). UN Independent International Commission of Inquiry on Syria reported in September 2016 that while stigma and trauma, sexual violence was also committed by governmental officials against male and female detainees. The report also documented some cases as evidence. The report also stated that the riot occurred inside the Hama Central Prison by detainees on $1^{\text {st }}$ May 2016 which constrained by forces resultant more injuries of prisoners.

\section{JABHAT AL-NUSRA AND ISIS REPRESSIONS AND ANNIHILATIONS}


Syria is not just destroying by regime only but other actors are also participating in demolition of land and people in which ISIS and Jabhat alNusra are the leading performers. IS uses homemade land mines, car bombs, suicidal attacks against regime forces and seizures, uninformed custodies, killings, and illicit blockades against civilians. In both the cases the proportion of anguish is increased of common Syrian people. The report of Human Rights Commission stated many killing actions conducted and claimed by IS and Jbhat al Nusra in different parts of Syria since 2013 to 2017 including:

- Homemade land mines attack in Manbij, a city in northern Syria, resulted hundreds of civilian killing including dozen of children and women.

- On January 17, at least 85 civilians and 50 Syrian soldiers killed during an offensive attack by ISIS in the city of Deir al-Zour.

- At Latakia governorate several car bombing and suicidal attacks killed more than 145 Alawites, on May 23, 2016.

- On February 21, 109 people killed and 235injured, by a series of ISIS bombings in Damascus and in Homs.

- ISIS also bombed northeast Syrian region, Qamishli, by exploding a truck bomb on July 27 which resulting killing of 48 people and injuring of 140 .

Above mention offensives are the few ones which accepted by Islamic State itself during 2016. Such kind of attacks is the routine incidents occurred by IS militants in Syria. In Raqqa the Islamic State has been known to publicly crucify transgressors in the town square (Erum, 2017, p.93). The cruel, inhuman extermination is the important part of their extortion policy to control the area.

\section{EXTERMINATION BY OTHER GROUPS}




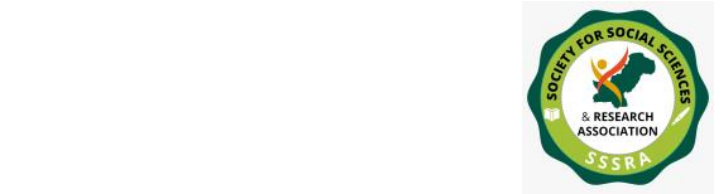

Other opposition groups are also not much behind of IS or Assad regime in inhuman killing of innocent Syrians. According to the 2017 report of Human Rights Commission, these groups launched extensive bombing and other armed attacks from their controlling zones to Aleppo, Damascus, Idlib, and Latakia and killed many civilians daily. These attacks usually targets crowded places like markets, educational institutes, hospitals, mosques and churches to increased number of deaths.

The northeastern Kurd populated land of Syria is presently controlled by The Democratic Union Party and its associated parties. They have set up local governance structures in its large portion. PYD trained militarily young boys and girls and uses them as front line solders, most of them are in an age group of 16 to 17 . These kids were mostly displaced during 2014 to2015 and it is a clear violation of UDHR (Universal Declaration of Human Rights). Brutality rules in Syria these days, it looks like that no one has feelings of mercy in the ancient territory of middle East.

\section{ROLE OF EXTERNAL POWERS IN SYRIAN CRISIS}

The civil war become more complex by the actions of regional states like Iran and Turkey and Western powers like USA and Russia within its borders.

United States Started its mission against IS in 2014 when they took sizable control in northeast region of Syria. Washington placed its troops for the support of Syrian Democratic Forces (SDF) who also fought against IS. About 2,000 troops stationed with air power and weapons, for local militias. The troops also provide weapons and training to the moderate rebel groups fighting against the Assad regime. White House also multiple times attacked on Syrian territory in 2017 and 2018. These attacks mostly conducted on IS controlled areas like Raqqa, and Deir ez-Zor city. Whereas on April 14, 2018 the coalition of USA, France and UK launched a series of missile attacks on Damascus chemical weapon facilities against the Douma chemical attack by Assad regime (BBC News, 2018, April 14). These attacks shows the concern of Trump administration but on the other hand it had not create any significant change in the life of people. 


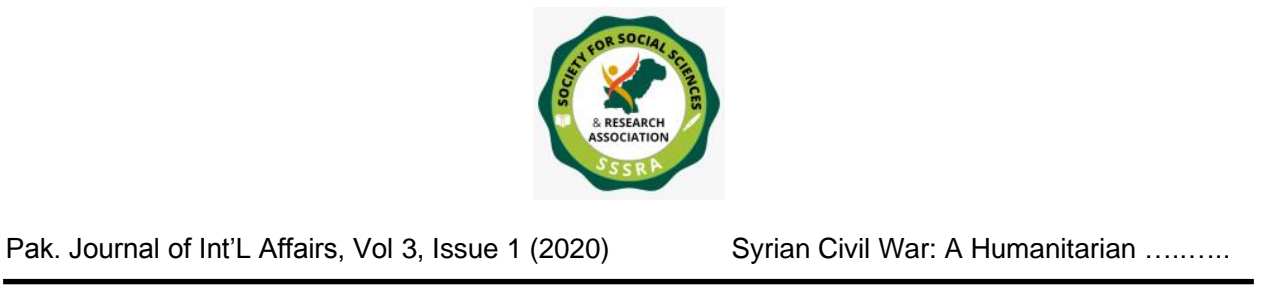

Russia also in also enter in the conflict in 2015 because of United States actions. Immediately after US attacks Moscow offer their weapon, air and ground forces support to the regime. President Putin not only offer but also launch air strikes against IS forces. Moscow and Washington both exhibited their deep concern regarding humanitarian loss but surprisingly IS controlled territories are still in there control and no significant change occur on ground, so the question arises that why they used such heavy artillery when they did not get any fruitful result. The question also rose that US used Tomahawk cruise missiles against whom because chemical weapons possessed by regime and targeted regions in the control of rebellion groups. Thus all western powers and their allies are confused and failed to reduce the intensity of civil war.

Iran was the major external player with the beginning of uprising since 2011. Initially Tehran provide military assistance to the regime which later transformed into full-fledged intervention against all regime's adversaries. The reason of Iranian involvement was the presence of Saudi Arabia and Israel on the borders of Syria and also for the support of Shia-Alawite regime resulted the increase in sectarian violence among the groups and made situation more intense. According to a report published by the U.S. Department of State in October 2018, Tehran has spent almost \$16 billion to undermine the Middle East by financing proxy wars in countries like Yemen, Iraq and Syria (VOA News, 2018, December 19). Respected details suspected the role of Tehran in the region.

The fourth player Turkey is bordering Syria with the Kurd populated region that are interconnected with Turkish Kurds. This may instigate animosity in Turkish Kurds therefore they supported Free Syrian Army (FSA) who fought against them. Turkey launched two military operation in Syria in 2016 and 2018 against IS and Kurd rebellions. Erdogan regime also claimed to participate in future US-allied operations in Syria which shows intentions of intervene in the foreign soil not for the sake of Humanitarian predicament of poor people but their own benefit.

\section{REFFUGY CRISIS OF SYRIA}




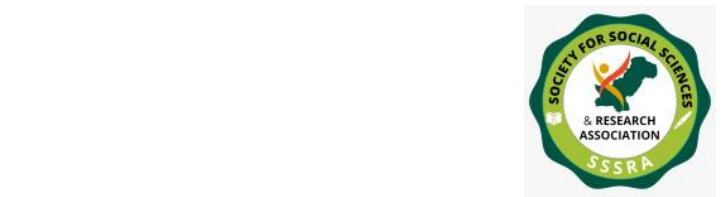

Generally, Refugees are the displaced individuals who enforced to leave their homeland due to unusual violent circumstances. The $1951 \mathrm{UN}$ Convention is defined the Status of Refugees as,

"refugees are individuals who, owing to a well-founded fear of being persecuted for reasons of race, religion, nationality, membership of a particular social group or political opinion, are outside the country of their nationality and are unable or, owing to such fear, unwilling to avail themselves of the protection of that country" (Griffiths \& O’Callaghan, 2002, p.267).

The Syrian refugee crisis started after the few months of civil war and increasing with the time, by the end of 2016, roughly 12 million Syrian are taken refuge in neighboring countries which become the half population of the country. (US for UNHCR The United Nation Refugee Agency, 2020). Whereas 6.1 million Syrians are displaced within the country called internally displaced people (IDPs). Lebanon hosting the major portion of refugees, where they lived a miserable life without any formal refugee camps. In Jordan, hosting over 660,000 Syrian refugees in which about $80 \%$ live outside the camps without proper system (US for UNHCR The United Nation Refugee Agency, 2020). Turkey also hosting the large number of Syrian refugees. International security of refugees is guaranteed under the 1951 Refugee Convention and 1967 Protocol but both Lebanon and Jordan have not signed this treaty thus, they are not bound to provide full refugee amenities to the refugees. United Nations Refugee Agency made effort to accommodate and facilitate Syrian refugees in all refugee camps but it is not a very tranquil process because they already burdened by refugees in other places of different nations such as Iraqi, Afghani, Rohingyians, Somalians etc.

\section{CONCLUSION}

Middle East known as the region of crisis because of religious, ethnic, political and social disparities existed in the nations. Similarly, Syria is also recognized as the country of conflicts where almost every group confront 


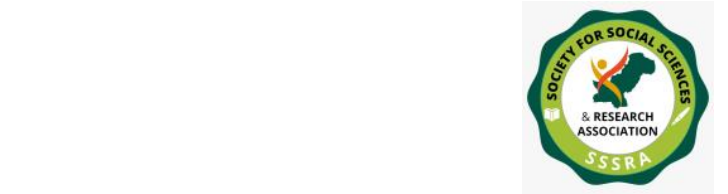

with its opponent. The Arab spring only highlighted the conflicts which deep down excavated in the soil of this land. Assad regime never realized the animosity existed in the people of Syria. Religious inequalities were always present in the country but it was never become an issue before uprising. Many analysts believed that external powers exploit the minor complications of the people and Assad regime. Scholars also claimed that United States and Russia influenced in the region and both are trying to wider their role in Middle East. On the other hand, non-state actors like IS and Al Qaida get a chance to impose their own kind of extreme thoughts in the label of religion and exhibiting such horrifying picture of violence that shading all former examples of torment, ferocity and brutality. Despite of illegal forces, so called democratic government of Bashar-al-Assad is also equally responsible of calamity of Syria.

Humanitarian crisis of the country is mounting on the extreme levels, bombing, be heading, ruthlessness are the routine activities. Half of the population are forced to become Refugee in neighboring countries. Syrian regime committing clear violations of international conventions but world powers are not doing any effective action against them nor they did anything against IS except condemnations and baseless sanctions. The international concerns are also not playing any significant role in terms of any effective peace-making solution between combatants. Syrians lives are in complete depression particularly the children's and women's life. They do not get enough food to keep them healthy nor can go schools to get education. Women's situation is not very different from kids instead poor health facilities make their lives more miserable. The seventh year of the civil war in Syria completed but the war is still continuing and resulting in losses, grievances, annihilation, deprivation of public services, constant internal displacement and loss of shelter and livelihoods. The civilization is lament and the prospects of peace are not very optimistic because the world and the regional powers have their own benefits therefore, they are more focusing on vocal condemnations rather than vigorous actions. 


\section{REFERENCES}

Baltes, C. M. (2016). Causes and Consequences of the Syrian Civil War. University of South Carolina - Columbia. https://scholarcommons.sc.edu/senior_theses/105/.

BBC News (2018, April 14). Syria air strikes: US and allies attack 'chemical weapons sites' https://www.bbc.com/news/world-middleeast-43762251,

Encyclopedia Britannica (2020). Sykes-Picot Agreement 1916, https://www.britannica.com/event/Sykes-Picot-Agreement)

Erlich, R. (2014). Inside Syria: The Backstory of Their Civil War and What the World Can Expect, New York: Prometheus Books.

Erum, R. (2017). Global Security and New Directions in US Foreign Policy, Moldova: Lambert Academic Publishing.

Ferris, E.G. \& Kirişci, K. (2016). The Consequences of Chaos: Syria's Humanitarian Crisis and the Failure to Protect, USA: Brookings Institution Press.

Griffiths, M. \& O’Callaghan, T. (2002). International Relations: The Key Concepts, New York: Routledge.

Haran, V.P. (2016). Roots of the Syrian Crisis, Institute of Peace and Conflict Studies: Special Report \#181.

www.ipcs.org/pdf_file/issue/RootsoftheSyrianCrisis_VPHaran.pdf

Human Rights Watch. (2017). Human Rights Watch world report 2017: events of 2016. New York: Seven Stories

Press.https://www.hrw.org/world-report/2017/country-chapters/syria

Jones, P. (2012). The Arab Spring: Opportunities and Implications. International Journal 67(2).

https://journals.sagepub.com/doi/abs/10.1177/002070201206700214. 
Lefèvre, R. (2013). Ashes of Hama: The Muslim Brotherhood in Syria. London: Hurst \& Company.

Manfreda, P. (2018, Feb 28) What Has Happened in Syria? Explaining The Syrian Civil War. Thought Co. https://www.thoughtco.com/currentsituation-in-syria-2353567

Solomon, J. \& Spindle, B. (2011). Syria Strongman: Time for 'Reform, Wall Street Journal, 312011.

http://www.wsj.com/articles/SB10001424052748704832704576114340 $\underline{735033236}$

scholarcommons.sc.edu/cgi/viewcontent.cgi?article $=1106 \&$ context $=$ sen ior_theses

Taki, M.(2012). BBC, Media Action, http://downloads.bbc.co.uk/mediaaction/pdf/syria.pdf

US for UNHCR The United Nation Refugee Agency. (2020). Refugee Statistics. Global Trends at the Glance.

https://www.unrefugees.org/refugee-facts/statistics/

VOA News, (2018, December 19). Syria: What's at Stake for US, Russia, Iran and Turkey. https://www.voanews.com/a/syria-whats-at-stake-for-usrussia-iran-and-turkey/4708689.html/

Weiss, M. \& Hassan, H. (2016). ISIS: Inside the Army of Terror. New York: Regan Arts. 